\title{
Does the Addition of Cotton Wastes Affect the Properties of Particleboards?
}

\author{
Mário Vanoli Scatolino ${ }^{1}$ (D), Thiago de Paula Protásio ${ }^{2}$ (D), Valéria Maria Souza ${ }^{3}$ (D), \\ Camila Laís Farrapo $^{1}$ (D), José Benedito Guimarães Junior ${ }^{1}$ (D), Déborah Soratto ${ }^{4}$ (D), \\ Rafael Farinassi Mendes ${ }^{1}$ (D), Lourival Marin Mendes ${ }^{1}$ \\ ${ }^{1}$ Universidade Federal de Lavras - UFLA, Lavras/MG, Brasil \\ ${ }^{2}$ Universidade Federal Rural da Amazônia - UFRA, Parauapebas/PA, Brasil \\ ${ }^{3}$ Universidade Federal de Goiás - UFG, Regional Jataí, Jataí/GO, Brasil \\ ${ }^{4}$ Universidade Federal de Mato Grosso do Sul - UFMS, Chapadão do Sul/MS, Brasil
}

\begin{abstract}
A wide range of materials for the development of new products can be obtained from natural resources. Good examples of these materials are lignocellulosic wastes, which are a good alternative for the production of particleboards. This study aimed to evaluate the feasibility of using cotton wastes in association to eucalyptus particles in the production of particleboards. Cotton waste proportions used were $0,10,20$ and $30 \%$. Urea formaldehyde (UF) adhesive was applied at $12 \%$, based on dry the weight of particles. Physical and mechanical tests were performed in order to evaluate panels. Water Absorption (2 and $24 \mathrm{~h}$ ) and Internal Bond (IB) showed not significant effect with increased percentage of cotton waste. Thickness Swelling ( 2 and $24 \mathrm{~h}$ ) of particleboards increased with increased percentage of waste material. The Modulus of Elasticity for cotton waste particleboards ranged from $726.47 \pm 99.98$ to $205.12 \pm 66.24 \mathrm{MPa}$, while the Modulus of Rupture ranged from $8.63 \pm 1.39$ to $3.87 \pm 0.75 \mathrm{MPa}$. According to results, cotton wastes could be added to particleboards up to the percentage of $9 \%$, being indicated for the manufacture of some types of furniture such as doors and sides.
\end{abstract}

Keywords: lignocellulosic waste, cotton culture, reuse, biomass. 


\section{INTRODUCTION}

Cotton stands out among Brazilian cultures producing large amounts of waste. Brazil is the world's fifth major cotton producer. In 2014, the Brazilian cotton production was approximately $1,412 \mathrm{t}$ (FAO, 2015). According to CONAB (2016), for each $100 t$ of cotton, $1 \mathrm{t}$ of waste is generated. "Capucho" is among these residues, which corresponds to cotton fruit after opening. Traditionally, cotton production is mainly intended for the textile industry, while wastes are used by small producers as substrate for planting of agronomic species and improvement of soil properties (Caldeira et al., 2008). Cotton waste presents a certain amount of cotton fibers in its composition that cannot to be removed after processing. The utilization of residues generated by the Brazilian agribusiness may be considered an alternative for the particleboard sector (Mendes et al., 2010). According to Guimarães et al. (2011), any lignocellulosic material has potential for being applied as raw material for particleboard production, which provides an opportunity for the reuse of forest-based and agroindustrial waste. With the growth of the wood panel industry, the demand for planting areas with currently used species of the genera Pinus sp. and Eucalyptus sp. also increased, as well as the search for new raw material options (Farrapo et al., 2014; Mendes et al., 2014). The literature has reported several attempts to produce more sustainable panels. These alternatives involve the use of natural adhesives (Goulart et al., 2012; Carvalho et al., 2014), low formaldehyde release (Roffael \& Behn, 2012) and alternative raw material, derived from lignocellulosic wastes such as sugarcane bagasse (Mendes et al., 2012), rice husk (Melo et al., 2009; César et al., 2017), maize cob (Scatolino et al., 2013, 2015; Sekaluvu et al., 2014), coffee husk (Mendes et al., 2010), peanut husk (Guler \& Buyuksari, 2011), corn straw (Silva et al., 2015), vine (Vitis vinifera L.) (Yeniocak et al., 2014), castor husk (Silva et al., 2016) and rapeseed straw (Dukarska et al., 2017).

In addition, many studies in literature have shown the mixture of agricultural wastes with wood species such as coffee husks in association to Eucalyptus urophylla (Mendes et al., 2010); castor husk and Pinus oocarpa (Silva et al., 2016) and maize cob to pine wood (Scatolino et al., 2015). All studies evaluated the influence of different proportions of lignocellulosic waste on the physical and mechanical properties of particleboards.
Cotton waste could be a potential alternative material for being applied in particleboard production due to the fact that it is basically composed of cellulose, hemicellulose and lignin. The aim of this study was to evaluate the potential of using cotton waste as raw material for particleboard production associated to eucalyptus wood through the results of its physical and mechanical properties.

\section{MATERIAL AND METHODS}

\subsection{Particle production and processing}

The agricultural waste used for panel production was cotton waste known as "capucho" (Figure 1). The material was provided by producers from the municipality of Chapadão do Sul, state of Mato Grosso do Sul, Brazil. The wood specie was Eucalyptus urophylla $\mathrm{x}$ Eucalyptus grandis hybrid from experimental planting (36 months) located in Jataí, state of Goiás, Brazil. Sliver particles from eucalyptus wood and cotton waste were obtained from processing in a mill. After production, particles were sieved and the content retained between $10(2.000 \mathrm{~mm})$ and $30(0.590 \mathrm{~mm})$ mesh sieve were selected for particleboard production. Subsequently, particles were dried to reach moisture content of $3 \%$.

\subsection{Basic density of the raw material}

The basic density of cotton waste was obtained by saturation of particles and subsequent volume measurement in a measuring cylinder. Particles were dried $\left(100 \pm 5^{\circ} \mathrm{C}\right)$ and the dry weight/saturated volume ratio was calculated. Eucalyptus wood was subjected to analysis to determine the basic density values according to procedures in NBR 11941 standard (ABNT, 2003a).

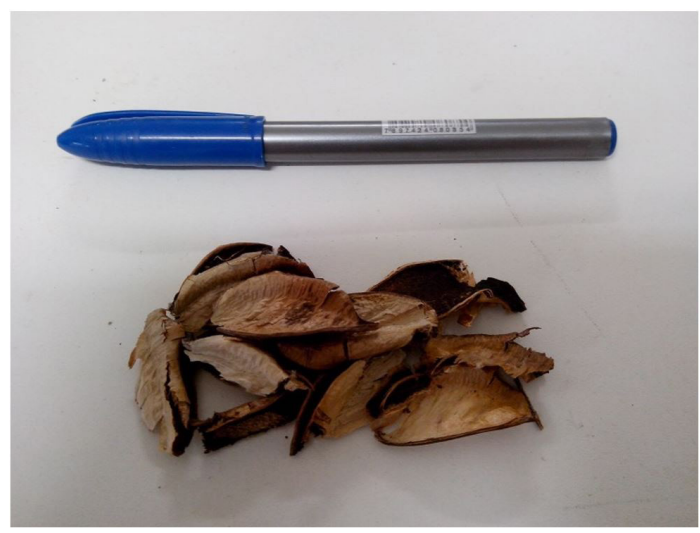

Figure 1. Cotton waste used for particleboard production. 


\subsection{Chemical analysis of materials}

For analysis of the chemical components of eucalyptus and cotton waste, the material retained between $40(0.420 \mathrm{~mm})$ and $60(0.250 \mathrm{~mm})$ mesh sieve was used. The material was subjected to analysis to determine the total content of extractives - NBR 14853 (ABNT, 2010a), lignin - NBR 7989 (ABNT, 2010b) and minerals - NBR 13999 (ABNT, 2003b).

\subsection{Particleboard production parameters}

The UF properties were: solid content $64.07 \%$, $\mathrm{pH} 8.48$ and viscosity $480 \mathrm{cP}$. The adhesive was applied at content of $12 \%$ based on the dry weight of particles. Particles were manually mixed to UF adhesive as proposed by Scatolino et al. (2017) and Guimarães et al. (2016). The mixture was pre-pressed at $0.5 \mathrm{MPa}$ (5 minutes) at room temperature and then, hot pressing was performed at $4.0 \mathrm{MPa}$ and temperature of $180{ }^{\circ} \mathrm{C}$ (20 minutes). The experimental design consisted of four eucalyptus wood and cotton waste combinations (Table 1). Three panels were produced for each treatment ( $250 \times 250 \times 15 \mathrm{~mm})$.

\subsection{Evaluation of panels and statistical analysis}

Once panels were acclimatized at temperature of $22 \pm 2^{\circ} \mathrm{C}$ and $65 \pm 5 \%$ of relative humidity, test samples were obtained using a circular saw. The compaction ratio was obtained by the relationship between the apparent particleboard density and the material used for its production (Equation 1).

Table 1. Experimental design for particleboard production.

Eucalyptus wood \% Cotton waste $\%$

\begin{tabular}{cc}
100 & 0 \\
90 & 10 \\
80 & 20 \\
70 & 30 \\
\hline
\end{tabular}

$$
C R=\frac{p d}{c w d x(c w \%)+e w d x(e w \%)}
$$

where: $p d$ is the apparent particleboard density $\left(\mathrm{g} / \mathrm{cm}^{3}\right)$; $c p d$ is the basic cotton waste density $\left(\mathrm{g} / \mathrm{cm}^{3}\right) ; c p \%$ is the cotton waste content; ewd is the basic eucalyptus wood density $\left(\mathrm{g} / \mathrm{cm}^{3}\right)$; and $e w \%$ is the eucalyptus wood content.

The physical and mechanical properties were based on standards provided in Table 2.

The experiment had a completely randomized design. As the aim of this study was to verify variations in the results of physical and mechanical properties as a function of the cotton waste percentage, data were subjected to ANOVA and regression analysis, both at $5 \%$ significance level.

\section{RESULTS AND DISCUSSION}

\subsection{Physical properties of particleboards}

Variation of the mean WA2h and WA24h values as a function of substitution of eucalyptus wood by cotton waste is shown in Figure 2. In both cases, linear regression was not significant at 5\% significance level.

This fact seems to be due to the higher amount of extractives present in cotton waste, which may have increased the hydrophobic characteristics of particleboards produced with the addition of cotton waste. The higher amount of extractives in cotton waste in comparison to wood was considerable and ranged from 5.11 to $22.32 \%$ (Table 3 ).

Extractives are hydrophobic compounds of low molecular weight that can occur in minimal or significant levels and depend of the species and geographical location of plants (Hardell \& Nilvebrant, 1999). According to Iwakiri (2005), higher amounts of extractives in lignocellulosic raw materials are related to decreased permeability and hygroscopicity of the material. In addition to the effect of extractives,

Table 2. Physical and mechanical properties of particleboards according to the respective standards.

\begin{tabular}{|c|c|}
\hline Properties & Standard \\
\hline Water Absorption after two and twenty-four hours of immersion (WA2h and WA24h) & \multirow{3}{*}{ ASTM - D1037 (ASTM, 2006) } \\
\hline Thickness Swelling after two and twenty-four hours of immersion (TS2h and TS24h) & \\
\hline Internal Bond (IB) ${ }^{\mathrm{b}}$ & \\
\hline Modulus of Rupture (MOR) and Modulus of Elasticity (MOE) ${ }^{c}$ & DIN $52362(\mathrm{DIN}, 1982)$ \\
\hline
\end{tabular}

${ }^{a}$ Average of 2 samples per panel; ${ }^{b}$ Average of 6 samples per panel; 'Average of 4 samples per panel. 
Table 3. Chemical composition and basic density of lignocellulosic materials.

\begin{tabular}{ccccc} 
Material & Basic Density & Extractives & Lignin & Ashes \\
\cline { 2 - 4 } & $\left(\mathbf{g} / \mathbf{c m}^{3}\right)$ & & $-1.07 \pm 0.20$ & $7.75 \pm 0.09$ \\
Cotton waste & $0.19 \pm 0.09^{*}$ & $22.32 \pm 1.30$ & 31.07 & $0.51 \pm 0.08$ \\
\hline Eucalyptus wood & $0.45 \pm 0.03$ & $5.11 \pm 0.87$ & $27.27 \pm 0.32$ & \\
\hline
\end{tabular}

${ }^{*}$ Standard deviation.

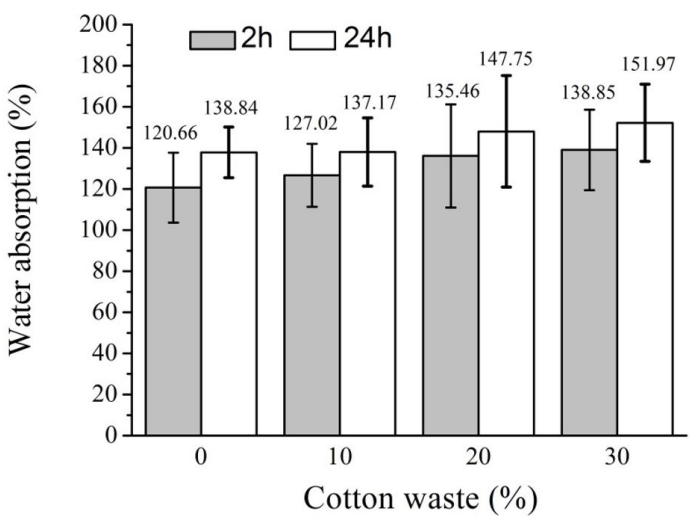

Figure 2. Water absorption of particleboards after 2 and $24 \mathrm{~h}$ of immersion in water; Not significant at 5\% significance level.

the high amount of lignin in cotton waste may have influenced the non-significant increase in water absorption values. Lignin is a hydrophobic material, with three-dimensional structure and highly branched, being classified as a polyphenol, which is composed of an irregular arrangement of several phenylpropane units (Silva et al., 2009). Cotton is known to have high cellulose values. Commonly, industrial cotton waste consists of $40 \%$ cellulose and $30 \%$ hemicelluloses (Sharma-Shivappa \& Chen, 2008). In addition, Wanassi et al. (2016) calculated the weight yield of fibers and found value of $61.20 \%$. Fibers are basically composed of hemicellulose and cellulose, which are able of absorbing water, influencing water absorption and swelling properties of panels.

Although the addition of waste did not significantly affect water absorption, linear regression adjusted for thickness swelling showed significant increase (Figure 3).

This fact is related to the low density of cotton waste. Low density values mean higher volume of particles in panels with higher residue proportions, consequently greater swelling. The increase of $1 \%$ in the amount of cotton waste in panels provides an increase of 0.3814 and $0.4022 \%$ in TS2h and TS24h, respectively. Mendes et al. (2010) found an increasing

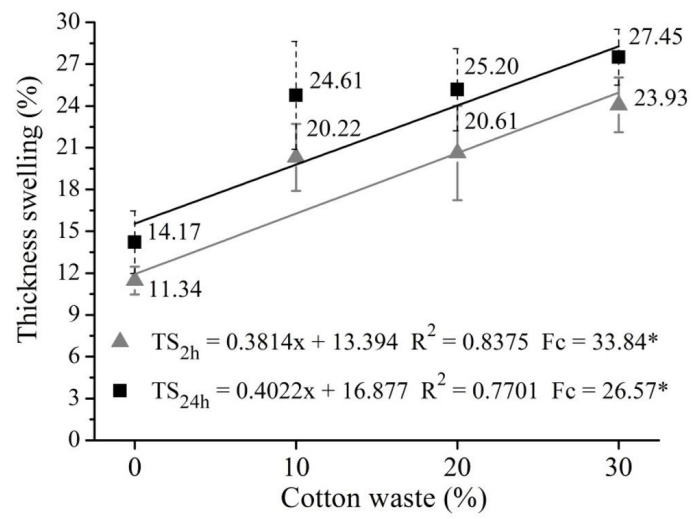

Figure 3. Thickness swelling of particleboards after 2 and $24 \mathrm{~h}$ of immersion in water; ${ }^{*}$ Significant at $5 \%$ significance level.

trend for the thickness swelling values when evaluating the association of coffee husk and Eucalyptus urophylla. The TS24h values ranged from 26 to $34 \%$, which were higher in comparison to those obtained in this study.

The mean apparent density values ranged from 0.52 to $0.55 \mathrm{~g} / \mathrm{cm}^{3}$, which characterized panels as low density (up to $0.55 \mathrm{~g} / \mathrm{cm}^{3}$ ) according to NBR 14810 standard (ABNT, 2013) (Table 4). The CS 236-66 standard (CS, 1968) stipulates maximum TS24h values of $30 \%$, considering low density particleboards produced with UF adhesive. Therefore, all treatments obtained values below those determined by the standard. The low cotton waste density value resulted in a significant increase in compaction ratio values as the waste percentage in panels was increased. Particleboards exclusively composed of eucalyptus wood showed compaction ratio values below the ideal range of 1.3-1.6 recommended by Maloney (1993). The low density of particleboards, in addition to the high density obtained for eucalyptus wood caused this effect.

\subsection{Mechanical properties of particleboards}

Variation of the mean internal bond values as a function of the percentage of substitution of eucalyptus wood by cotton waste is shown in Figure 4. Linear regression was not significant at $5 \%$ significance level. 


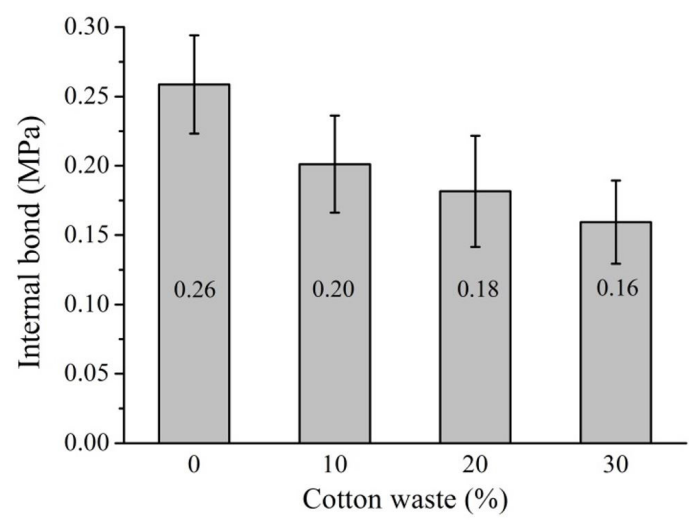

Figure 4. Internal bond of particleboards; Not significant at $5 \%$ significance level.

Table 4. Apparent density and compaction ratio of particleboards.

\begin{tabular}{ccc}
$\begin{array}{c}\text { Cotton waste } \\
(\%)\end{array}$ & $\begin{array}{c}\text { Apparent } \\
\text { density }\left(\mathrm{g} / \mathbf{c m}^{3}\right)\end{array}$ & $\begin{array}{c}\text { Compaction } \\
\text { ratio }\end{array}$ \\
\hline 0 & $0.53 \pm 0.02^{*} \mathrm{~A}$ & $1.2 \pm 0.04 \mathrm{~A}$ \\
10 & $0.54 \pm 0.02 \mathrm{~A}$ & $1.3 \pm 0.05 \mathrm{~B}$ \\
\hline 20 & $0.55 \pm 0.06 \mathrm{~A}$ & $1.4 \pm 0.09 \mathrm{C}$ \\
\hline 30 & $0.52 \pm 0.02 \mathrm{~A}$ & $1.4 \pm 0.06 \mathrm{C}$ \\
\hline
\end{tabular}

${ }^{*}$ Standard deviation; Means followed by the same letter in the column do not differ statistically by the Scott-Knott test at 5\% significance.

Considering low-density particleboards, Guler \& Buyuksari (2011) found values close to $0.16 \mathrm{MPa}$ for IB when evaluating particleboards produced with peanut husk. Similarly, Guler \& Ozen (2004) obtained $0.25 \mathrm{MPa}$ for particleboards produced with cotton stalk. Silva et al. (2016) found no significant effect on IB values associating castor husk to eucalyptus wood for particleboard production (from 0.91 to $1.1 \mathrm{MPa}$ ). The CS 236-66 standard (CS, 1968) establishes 0.14 MPa as minimum IB value considering low density panels produced with UF adhesive. Therefore, all treatments reached values established by the standard.

Variations in the mean modulus of elasticity (MOE) and modulus of rupture values (MOR) to static bending as a function of the percentage of substitution of eucalyptus wood by cotton waste are shown in Figures 5 and 6, respectively. Quadratic regression was significant at 5\% significance level in both cases.

This result was due to the higher compaction ratio of panels with addition of cotton waste. As previously discussed, higher compaction ratios indicate higher number of particles per panel. Under these conditions,

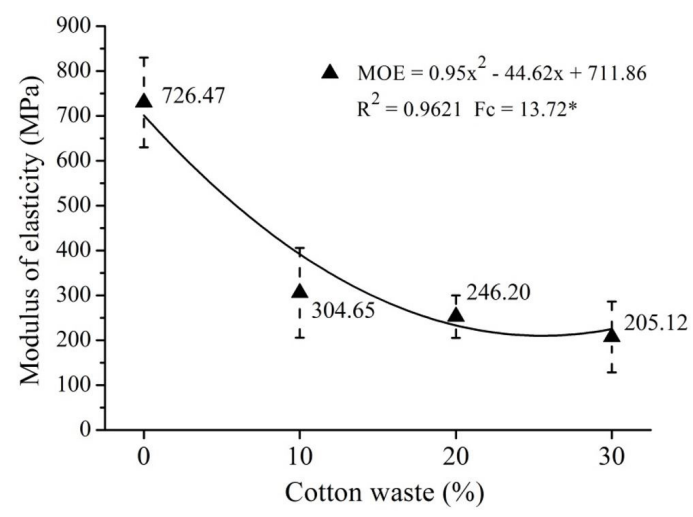

Figure 5. Modulus of elasticity of particleboards; *Significant at $5 \%$ significance level.

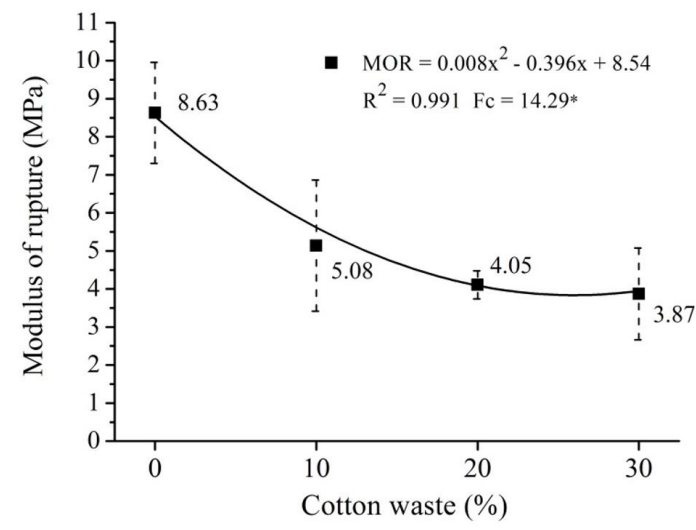

Figure 6. Modulus of rupture of particleboards; *Significant at $5 \%$ significance level.

the application of the same content of adhesive decreases its availability per particle, resulting in lower values for these properties. In addition, the low basic cotton waste density directly influences the cell wall thickness and therefore the strength and stiffness of the material. This may be another determining factor for the decreasing MOE and MOR values.

Scatolino et al. (2013) evaluated different proportions of maize cob in association with Pinus oocarpa wood for particleboard production (8\% UF adhesive) and found the same trend observed in this research. Similarly, Mendes et al. (2012) added sugarcane bagasse to particleboards (25, 50 and $75 \%$ ) and found values from 842.5 to $825.7 \mathrm{MPa}$ and 11.4 to $9.5 \mathrm{MPa}$, respectively for MOE and MOR. Guler \& Ozen (2004) found values of approximately 7.32 for MOR when evaluating particleboards added of cotton stalk. The MOE values were lower than the minimum value required by CS 
236-666 standard (1968) (CS, 1968) (1052 MPa) for all treatments. When investigating the minimum value required for MOR (5.6 MPa) considering the same standard, the quadratic regression adjusted for this property indicates $9 \%$ as the limit for the addition of cotton waste in particleboards.

\section{CONCLUSION}

Particleboards were successfully produced associating several percentages of cotton waste to eucalyptus wood and their physical and mechanical properties were evaluated. The increased addition of cotton waste did not compromise the physical properties of particleboards; however, caused reduction of their mechanical properties. All treatments were consistent with CS 236-66 commercialization standard (1968) for thickness swelling and internal bond, considering low density particleboards. None of the treatments met the requirements of the standard for MOE, while the maximum cotton waste content that could be added to reach requirements for MOR is $9 \%$. In general, particleboards with the addition of cotton waste may be indicated for the manufacture of some types of furniture such as doors and sides.

\section{ACKNOWLEDGEMENTS}

The authors are grateful for the financial support provided by Conselho Nacional de Desenvolvimento Científico e Tecnológico (CNPq), Fundação de Amparo à Pesquisa do Estado de Minas Gerais (FAPEMIG), Fundação de Amparo à Pesquisa do Estado de Goiás (FAPEG) and Coordenação de Aperfeiçoamento de Pessoal de Nível Superior (Capes).

\section{SUBMISSION STATUS}

Received: 14 mar., 2017

Accepted: 24 jan., 2018

\section{CORRESPONDENCE TO}

\section{Mário Vanoli Scatolino}

Departamento de Ciências Florestais, Universidade Federal de Lavras - UFLA, Campus Universitário, CP 3037, CEP 37200-000, Lavras, MG, Brasil

e-mail:mario_paraiso@hotmail.com

\section{FINANCIAL SUPPORT}

Fundação de Amparo à Pesquisa do Estado de Minas Gerais (FAPEMIG), (Grant/Award: PPM-00312-15).

\section{REFERENCES}

American Society for Testing and Materials - ASTM. ASTM-D1037. Standard Test Methods for Evaluating Properties of Wood-Base Fiber and Particle Panel Materials. Rio de Janeiro: ABNT; 2006.

Associação Brasileira de Normas Técnicas - ABNT. ABNT - NBR 11941: Wood - Determination of basic density. Rio de Janeiro: ABNT; 2003a.

Associação Brasileira de Normas Técnicas - ABNT. ABNT - NBR 13999: Paper, board, pulp and wood Determination of residue (ash) on ignition at $525{ }^{\circ} \mathrm{C}$. Rio de Janeiro: ABNT; 2003b.

Associação Brasileira de Normas Técnicas - ABNT. ABNT - NBR 14853: Determination of soluble matter in ethanol-toluene and in dichloromethane and in acetone. Rio de Janeiro: ABNT; 2010a.

Associação Brasileira de Normas Técnicas - ABNT. ABNT - NBR 7989: Pulp and wood - Determination of acid-insoluble lignin. Rio de Janeiro: ABNT; 2010b.

Associação Brasileira de Normas Técnicas - ABNT. ABNT - NBR 14810: Medium density particleboards Part 2: Requirements and test methods. Rio de Janeiro: ABNT; 2013.

Caldeira MVW, Blum H, Balbinot R, Lombardi KC. Use of cotton residue in substrate on production of forest seedlings. Revista Acadêmica Ciências Agrárias e Ambientais 2008; 6(1): 191-202.

Carvalho AG, Mori FA, Mendes RF, Zanuncio AJV, Silva MG, Mendes LM et al. Use of tannin adhesive from Stryphnodendron adstringens (Mart.) Coville in the production of OSB panels. European Journal of Wood and Wood Products 2014; 72(4): 425-432. http://dx.doi. org/10.1007/s00107-014-0797-5.

César AAS, Bufalino L, Mendes LM, Mesquita RGA, Protásio TP, Mendes RF et al. Transforming rice husk into a high-added value product: potential for particleboard production. Ciência Florestal 2017; 27(1): 303-313.

Commercial Standard - CS. CS 236-66: mat formed wood particleboard. Geneva: CS; 1968.

Companhia Nacional de Abastecimento - CONAB. National Supply Company Bulletin [online]. 2016 [cited 2016 Dec 21]. Available from: www.conab.gov.br

Deutsches Institut für Normung - DIN. DIN 52362: Testing of wood chipboards bending test, determination of bending strength. Germany: Deutsches Institut für Normung, 1982. Normen fur Holzfaserplaten Spanplatten Sperrholz. 
Dukarska D, Czarnecki R, Dziurka D, Mirski R. Construction particleboards made from rapeseed straw glued with hybrid pMDI/PF resin. European Journal of Wood and Wood Products 2017; 75(2): 175-184. http:// dx.doi.org/10.1007/s00107-016-1143-X.

Farrapo CL, Mendes RF, Guimarães JB Jr, Mendes LM. Utilization of Pterocarpus violaceus wood in the particleboard production. Scientia Forestalis 2014; 42(103): 329-335.

Food and Agriculture Organization of the United Nations - FAO. FAOSTAT [online]. Rome: FAO; 2015 [cited 2016 Dec 21]. Available from: http://faostat3.fao. org/browse/Q/QC/E

Goulart SL, Mori FA, Almeida NF, Mendes RF, Mendes LM. Shear strength of plywood produced with tannin adhesive of Stryphnodendron adstringens (barbatiman). Floresta e Ambiente 2012; 19(3): 308-315. http://dx.doi. org/10.4322/floram.2012.036.

Guimarães JB Jr, Mendes LM, Mendes RF, Mori FA. Wood particleboards made from residues obtained in the veneer production of eucalypt species and provenances. Cerne 2011; 17(4): 443-452.

Guimarães JB Jr, Xavier MM, Santos TS, Protásio TP, Mendes RF, Mendes LM. Addition of sorghum culture waste in eucalyptus particleboards. Pesquisa Florestal Brasileira 2016; 36(88): 435-442.

Guler C, Buyuksari U. Effect of production parameters on the physical and mechanical properties of particleboards made from peanut (Arachis hypogaea L.) husk. BioResources 2011; 6(4): 5027-5036.

Guler C, Ozen R. Some properties of particleboards made from cotton stalks (Gossypium hirsitum L.). Holz als Roh- und Werkstoff 2004; 62(1): 40-43. http://dx.doi. org/10.1007/s00107-003-0439-9.

Hardell HL, Nilvebrant NO. A rapid method to discrimination between free and esterified fatty acids by pyrolytic methylati on using tetramethyl ammonium acetate or hydroxide. Journal of Analytical and Applied Pyrolysis 1999; 52(1): 1-14. http://dx.doi.org/10.1016/S0165-2370(99)00035-2.

Iwakiri S. Painéis de madeira reconstituída. Curitiba: FUPEF; 2005.

Maloney TM. Modern particleboard and dry-process fiberboard manufacturing. 2. ed. São Francisco: Miller Freeman; 1993

Melo RR, Santini EJ, Haselein CR, Martins Stangerlin D. Properties of wood and rice husk particleboard in different proportions. Ciência Florestal 2009; 19(4): 449-460.

Mendes RF, Mendes LM, Guimarães JB Jr, Mori FA, César AAS. Effect of the incorporation of coffee husks on the physico-mechanical properties of Eucalyptus urophylla S.T. Blake particleboards. Ciência e Agrotecnologia 2010; 34(3): 610-617. http://dx.doi.org/10.1590/S141370542010000300012 .

Mendes RF, Mendes LM, Guimarães Júnior JB, Santos RC, César AAS. Association effect of sugar cane bagasse, type and levels of adhesive on particleboard production. Ciência Florestal 2012; 22(1): 187-196.

Mendes RF, Mendes LM, Mendonça LL, Guimarães JB Jr, Mori FA. Quality of homogeneous particleboard produced with Eucalyptus urophylla clone wood. Cerne 2014; 20(2): 329-336. http://dx.doi.org/10.1590/010477 60.201420021273

Roffael E, Behn C. On the influence of binder content in particleboards bonded with resins of high and low molar ratio on the formaldehyde release measured by the perforator method. European Journal of Wood and Wood Products 2012; 70(6): 819-822. http://dx.doi.org/10.1007/ s00107-012-0622-y.

Scatolino MV, Costa AO, Guimarães JB Jr, Protásio TP, Mendes RF, Mendes LM. Eucalyptus wood and coffee parchment for particleboard production: physical and mechanical properties. Ciência e Agrotecnologia 2017; 41(2): 139-146. http://dx.doi.org/10.1590/141370542017412038616 .

Scatolino MV, Protásio TP, Mendes RF, Mendes LM. Thermal stability of Pinus oocarpa and maize cob particleboards. Ciência e Agrotecnologia 2015; 39(4): 348-354. http:// dx.doi.org/10.1590/S1413-70542015000400005.

Scatolino MV, Silva DW, Mendes RF, Mendes LM. Use of maize cob for producption of particleboard. Ciência e Agrotecnologia 2013; 37(4): 330-337. http://dx.doi. org/10.1590/S1413-70542013000400006.

Sekaluvu L, Tumutegyereize P, Kiggundu N. Investigation of factors affecting the production and properties of maize cob-particleboards. Waste and Biomass Valorization 2014; 5(1): 27-32. http://dx.doi.org/10.1007/s12649-013-9228-9.

Sharma-Shivappa RR, Chen Y. Conversion of cotton wastes to bioenergy and value-added products. American Society of Agricultural and Biological Engineers 2008; 51(6): 2239-2246.

Silva DW, Farrapo CL, Ribeiro DP, Mendes RF, Mendes LM, Scolforo JRS. MDP with particles of eucalyptus and corn straw. Scientia Forestalis 2015; 43(108): 853-862.

Silva DW, Scatolino MV, Prado NRT, Mendes RF, Mendes LM. Addition of different proportions of castor husk and pine wood in particleboards. Waste and Biomass Valorization 2016; 74: 1-7.

Silva R, Haraguchi SK, Muniz EC, Rubira AF. Applications of lignocellulosic fibers in poymer chemistry and in composites. Quimica Nova 2009; 32(3): 661-671. http:// dx.doi.org/10.1590/S0100-40422009000300010.

Wanassi B, Azzouz B, Hassen MB. Value-added waste cotton yarn: optimization of recycling process and spinning of reclaimed fibers. Industrial Crops and Products 2016; 87: 27-32. http://dx.doi.org/10.1016/j.indcrop.2016.04.020.

Yeniocak M, Göktaş O, Erdil YZ, Ozen E. Investigating the use of vine pruning stalks (Vitis Vinifera L. CV. Sultani) as raw material for particleboard manufacturing. Wood Research 2014; 59(1): 167-176. 